\title{
The role of higher education libraries in promoting sustainable development - an example of the practice of the library at the Faculty of Civil Engineering and Architecture Osijek
}

\author{
Vesna Zobundžija \\ Josip Juraj Strossmayer University of Osijek, Faculty of Civil Engineering and Architecture, \\ B.Lib., vesnaz@gfos.hr \\ Zlata Dolaček-Alduk \\ Josip Juraj Strossmayer University of Osijek, Faculty of Civil Engineering and Architecture, \\ Ph.D C.E., zlatad@gfos.hr
}

\begin{abstract}
Sustainable development implies the harmonization of economic and social development with the preservation of natural resources for future growth. Libraries, as centers of education and open access to information, play an important role in green literacy and the promotion of knowledge about a sustainable environment. Libraries are also drivers of change that can make a significant contribution to addressing sustainability issues and achieving the goals of the UN 2030 Agenda for Sustainable Development through new services and activities. The Library at the Faculty of Civil Engineering and Architecture Osijek seeks to contribute to the achievement of planned goals for sustainable development related to education and availability of information, environmental protection and sustainable construction. The paper describes the educational and information resources that the library provides in material form and on online platforms, as well as activities that promote environmental awareness and user participation in green activities.
\end{abstract}

Key words: sustainable development, green literacy, higher education libraries, green libraries

\section{Uloga visokoškolskih knjižnica u promoviranju održivog razvoja - primjer prakse knjižnice Građevinskog i arhitektonskog fakulteta Osijek}

Sažetak: Održivi razvoj podrazumijeva usklađenost gospodarskog i društvenog razvoja s očuvanjem prirodnih dobara za budući rast i razvoj. Važnu ulogu u zelenom opismenjavanju i promicanju znanja o održivom okolišu imaju knjižnice, kao središta obrazovanja i otvorenog pristupa informacijama. Knjižnice su i pokretači promjena koje novim uslugama i aktivnostima mogu bitno doprinijeti rješavanju problema održivosti i ostvarivanju ciljeva UNove Agende 2030 za održivi razvoj. Knjižnica Građevinskog i arhitektonskog fakulteta Osijek nastoji doprinijeti ostvarivanju planiranih ciljeva za održivi razvoj koji su vezani uz obrazovanje i dostupnost informacija, zaštitu okoliša i održivu gradnju. U radu su opisani obrazovni i informacijski resursi koje knjižnica osigurava u materijalnom obliku i na mrežnim platformama te aktivnosti kojima promiče ekološku osviještenost i sudjelovanje korisnika u zelenim aktivnostima.

Ključne riječi: održivi razvoj, zelena pismenost, visokoškolske knjižnice, zelene knjižnice 
Zobundžija, V., Dolaček-Alduk, Z.

The role of higher education libraries in promoting sustainable development - an example of the practice of the library at the Faculty of Civil Engineering and Architecture Osijek

\section{INTRODUCTION}

Sustainable development, ecology, climate change control, environmental protection and energy efficiency are subjects that have been distinctly topical and present in all spheres of life in recent years. Rapid technological development, accompanied by the accumulation of waste and pollution, overuse of raw materials and uncontrolled energy consumption, put the natural balance at risk and caused climate change. Every day we witness the consequences of global warming, disappearance of coral reefs, extinction of wild species, which many scientists emphasize is happening precisely because of human encroachment on wild ecosystems.

Numerous reports and documents warning and alerting of the urgent need for moderate use of natural resources have not yet been taken seriously enough. Sustainable development implies the preservation of natural resources for future growth, and is possible only by using renewable resources, minimizing the use of non-renewable resources and generating only biodegradable emissions. Achieving these goals requires a fundamental change in people's habits and behavior [1]. The coronavirus pandemic that hit the entire world in 2020 and forced people into isolation has caused air pollution, resulting from the burning of fossil fuels, to fall to record low levels due to traffic restrictions. Nature has sent us a clear message, it is the last moment to give up old habits and make room for new, ecological, more natural, holistic approaches to life and thus preserve this unique planet for ourselves and future generations.

Green literacy is a key link in understanding and solving the described problems and implies a process in which individuals and institutions will acquire knowledge, skills and determination to solve environmental problems by spreading awareness of sustainable development. All sectors of education and science have become actively involved in green literacy, including libraries as institutions that are centers of information and education of their users, but also promoters of new ideas, services and activities by which they can contribute to solving the sustainability problem.

\section{THE PATH TO GREEN AWARENESS}

The negative consequences of economic development and human lack of concern for nature have been discussed for decades now. The Limits to Growth report on exponential economic and population growth with limited supply of resources was a kind of warning about the possible and undesirable consequences of economic growth. This report also instigated other initiatives intended to stop the uncontrolled exploitation of natural resources, pollution of water and air and the greenhouse effect [1]. However, the first official documents date as late as the 1990s. The World Commission on Environment and Development issued strategic recommendations and defined in 1987 the concept of sustainable development as "development that meets the needs of the present without compromising the ability of future generations to meet their own needs" [2]. The first official statement on environmental sustainability in higher education, the Talloires Declaration [3], was signed in 1990, and it was signed by the presidents, rectors and vice-chancellors of universities from all regions of the world. Aware of their role in education, science and information sharing, they defined measures to save the planet in ten points: raising awareness of sustainable development, creating an institutional culture of sustainability, educating environmentally responsible citizens, promoting environmental literacy for all, implementing institutional ecology, involving all stakeholders, cooperation for an interdisciplinary approach, increasing the capacity of primary and secondary schools, expanding services and responses at the national and 
Zobundžija, V., Dolaček-Alduk, Z.

The role of higher education libraries in promoting sustainable development - an example of the practice of the library at the Faculty of Civil Engineering and Architecture Osijek

international level, and maintaining the momentum [4]. Numerous documents, declarations and action plans followed, but international documents concluded by the United Nations, as the main global body for creating sustainable development guidelines, are considered to be the most important [5].

In order to achieve the principles, values and practices of sustainable development, it is necessary to profoundly change people's habits and behaviors. To this end, the United Nations declared the Decade of Education for Sustainable Development 2005-2014 (DESD), and the World Conference on Sustainable Development was organized in September 2015. The member states of the United Nations adopted the Sustainable Development Program until 2030, called the 2030 Agenda. The document calls for social responsibility at all levels by achieving 17 goals that should eradicate poverty, inequality and injustice and address climate change issues by 2030 throughout the world [5]. The International Federation of Library Associations and Institutions (IFLA) actively works to promote the role of libraries in meeting the sustainable development goals related to education and learning for all, preservation of culture, access to information and universal literacy, including digital, media and information literacy and skills. Libraries are identified as key institutions that contribute to a more effective achievement of the planned outcomes of sustainable development goals by providing access to information [6].

Croatian libraries have joined the program of social responsibility and implementation of sustainability by planning and implementing various activities through information and education for sustainable development, green literacy and sustainable thinking at the social, economic and environmental level [7]. The Green Library, as an idea and project, was launched in Croatia by the Librarian Association of Istria in 2011 [8]. The goal of the project is to educate the public and spread awareness of a sustainable society and the necessity to protect the environment, specifically through the project website, documentary showings, expert lectures, forums and presentations of books with environmental themes.

The term green library is most often used in the sense of a building that is designed and constructed so as to have the least possible adverse impact on the environment (sustainable in terms of building materials, application of energy efficient measures and the use of renewable energy sources, as well as responsible waste management). The second meaning is related to library programs and services, aimed at developing green literacy, or raising awareness and information about a sustainable society and environmental protection [5].

Due to the very high requirements placed on investors, designers and builders, in Croatia there is currently no certified green library building, i.e. a building that reduces consumption of energy sources by at least $50 \%$, emission of carbon dioxide by $40 \%$, while having a positive effect on satisfaction and health, and thereby the productivity and creativity of building users [9]. The only exception is the building of the Karlovac City Library "Ivan Goran Kovačić", which is the first purpose-designed building for public libraries, opened to the public in 1976. Since the original design was only partly realized, construction was resumed, and in 2007 an added part was opened. This part is energy efficient, built of harmless and durable materials, with green roof, and furniture made of natural materials was also selected. The old part of the building was renovated in 2019 according to the energy renovation project, so it can be said that the Karlovac library is now an energy sustainable building [10]. However, thanks to the enthusiasm and creativity of librarians, library green programs are beginning to be implemented in libraries throughout Croatia in order to educate the public and spread awareness of a sustainable society and the necessity to protect the environment. In 2012, the National and University Library in Zagreb opened the first Green Energy Efficiency Library (GEEL), a collection of materials that brings together professional publications and brochures published within implementation of the project Promoting Energy Efficiency in Croatia (EE project). In 2014, the City and University Library of Osijek organized a series of workshops Permaculture in Cities, and in the same year the Croatian Library 
Zobundžija, V., Dolaček-Alduk, Z.

The role of higher education libraries in promoting sustainable development - an example of the practice of the library at the Faculty of Civil Engineering and Architecture Osijek

Association in Split established the Working Group for Green Libraries for the purpose of promoting sustainable development and environmental protection through library programs at the national level. In 2016, the National and University Library in Zagreb presented the project Green Library for Green Croatia, which was launched to educate and sensitize users, especially students, for protection and preservation of nature and the environment, or natural resources as an important element of Croatian cultural heritage [5]. In November 2018, the $1^{\text {st }}$ International Conference on Green Libraries Let's Go Green! was organized at the National and University Library in Zagreb and the National Park Brijuni, where the latest trends in the development of green librarianship and ecology were presented and experiences and examples of good practice were exchanged.

The higher education libraries of the Josip Juraj Strossmayer University of Osijek very quickly responded to the call to join the green libraries movement and to introduce responsible and ecological operation in library programs. In April 2016, the Library of the Faculty of Economics Osijek organized a round table entitled Creating Green Libraries with the aim of joining the Green Library project and exchanging experiences and presenting environmental projects and activities conducted by individual libraries, participants of the Round Table. The Library of the Faculty of Law Osijek joined the project Green Energy Efficiency Library, displaying a shelf with GEEL professional publications, to make them more accessible to professionals, members of the academic community, students and citizens and thus raise awareness of responsible behavior in energy use through the use of energy efficient measures as well as renewable energy sources. The Library of the Faculty of Education Osijek joined the Green Library project in 2016 and since then has been continuously conducting various green activities in partnership with kindergartens and primary schools, believing that teaching about everything, including the need to preserve the Earth, should begin as early as possible.

\section{PROMOTING SUSTAINABILITY IN THE LIBRARY OF THE FACULTY OF CIVIL ENGINEERING AND ARCHITECTURE OSIJEK}

Higher education libraries have a new, proactive role in the context of social responsibility they should be a tool for achieving sustainable development. The quality of library services is no longer measured only by collecting and storing information sources, but also by ensuring the availability and free access to books and ideas, adhering to the principles of sustainability and environmental protection, building a responsible relationship with the local community, improving the working environment in the library and the institution of which it is a part, and by green and environmental programs and activities [7]. By actively and responsibly pursuing their expanded mission, higher education libraries can make a significant contribution to achieving the goals of the UN 2030 Agenda for Sustainable Development.

The Library of the Faculty of Civil Engineering and Architecture Osijek has recognized the importance of active participation in green literacy of users, implementing in its program and operations primarily those goals that are related to quality education (Global Goal 4), sustainable cities and communities (Global Goal 11), climate protection (Global Goal 13) and free access to information (Global Goal 16.10).

\subsection{Goal 4_Quality education: Ensure inclusive and quality education and promote lifelong learning opportunities}

In May 2016, the Faculty of Civil Engineering and Architecture Osijek moved into a new, modern building in the university campus, in which employees and students have excellent 
Zobundžija, V., Dolaček-Alduk, Z.

The role of higher education libraries in promoting sustainable development - an example of the practice of the library at the Faculty of Civil Engineering and Architecture Osijek

conditions for further development and better performance of teaching, research and professional work. The Library is located on the ground floor, in a room of about $270 \mathrm{~m}^{2}$. It is equipped with new and modern furniture and has a reading room with 40 work places that are all equipped for work on computers and with Internet connections (Figure 1). Since the walls are actually glass walls, facing east and north, the library and reading room are full of light, comfortably air-conditioned, located separately from corridors and classrooms to ensure peace and silence. A beautiful and comfortable space is undoubtedly a very important factor in creating a stimulating atmosphere for students to work and study.

The Legere Club (after the Latin lego, legere $=$ read), the entrance room of the library with an area of $43 \mathrm{~m}^{2}$, was formally opened in early 2020. It is arranged on the model of similar rooms at many world's universities where they are sometimes located within the library, and sometimes as separate rooms for relaxation and rest, reading, meditation, and prayer (Figure 2). Located next to the reading room, from which it is separated by a glass wall, this previously unused space is turned into a living room for students and employees, intended for informal gatherings, socializing, reading and entertainment with social games.

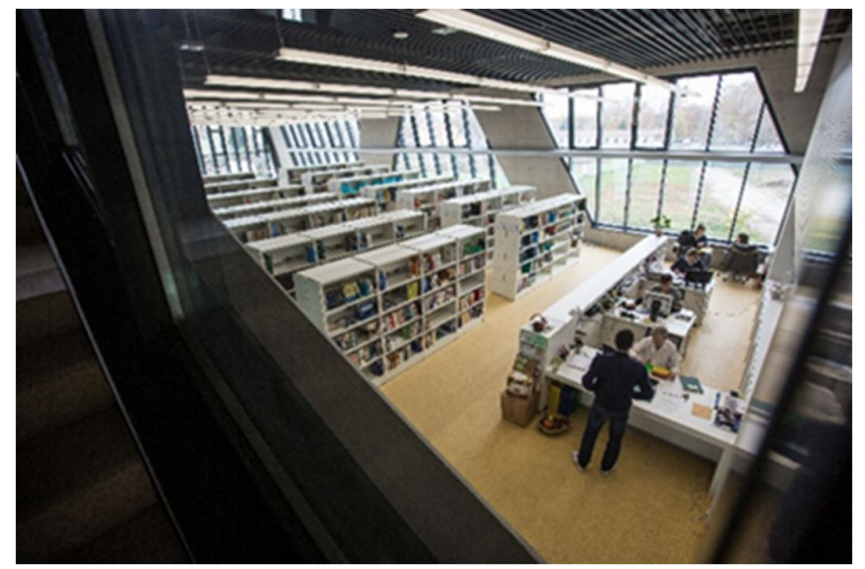

Figure 1. Library space of the Faculty of Civil Engineering and Architecture Osijek (FCEAO)

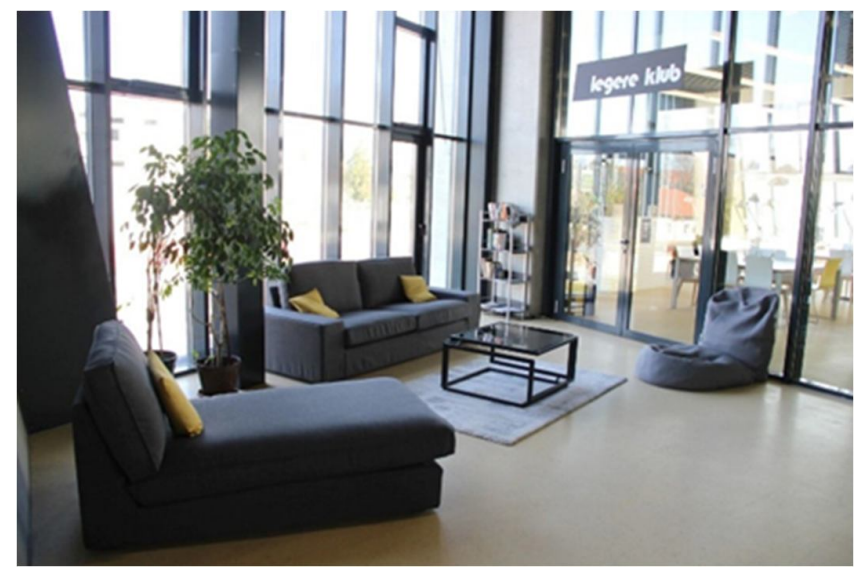

Figure 2. Legere Club space

The library holdings, which include domestic and foreign professional literature in the field of civil engineering and architecture and related areas specified by the curriculum 
Zobundžija, V., Dolaček-Alduk, Z.

The role of higher education libraries in promoting sustainable development - an example of the practice of the library at the Faculty of Civil Engineering and Architecture Osijek

(mathematics, physics, geodesy, geology, economics), consist of slightly less than 10,000 volumes and is located on the shelves in open access. Reference literature (encyclopedias, lexicons, dictionaries, manuals) and professional and scientific journals are displayed in the reading room and, like other materials, are available for work in the reading room. In addition to informative and educational content that is published on the Library's web page, lectures and workshops, usually related to searching databases and other e-resources, open access and copyright, and the like, are organized for students and teaching staff.

Global trends in the modern understanding of the idea of university are based on the socalled creative economy, which implies that they should be, in addition to educational and scientific, local and regional creativity centers. Curricula are adapted to the needs of the market, and the focus shifts from business competencies to creative relationships and communication. The new model of education implies introducing into curricula various creative programs and projects that are aimed at attracting students and developing their individual creativity and artistic expression [11]. The Library of the Faculty of Civil Engineering and Architecture Osijek seeks to adapt to these trends and take on the role of a cultural center and the main driver and supporter of creative activities at the Faculty. As part of projects marking various events (Croatian Book Month, Book Night, Croatian Language Days, International Book Giving Day, etc.), the Library organizes presentations of new, mostly professional and scientific books, professional and popular science lectures, literary and musical evenings, exhibitions, student workshops and themed pub quizzes. Most of these activities are also open to the public and are promoted through social networks, radio and television (Figure 3).

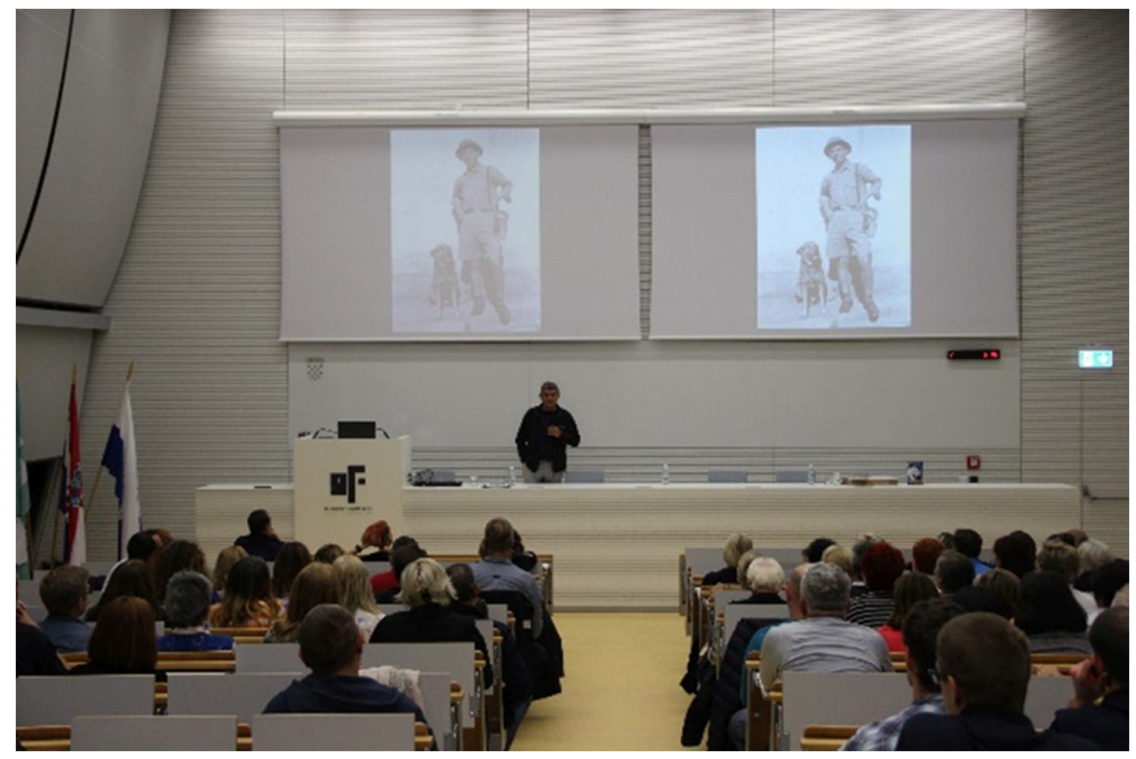

Figure 3. Lecture Seven Peaks by Stipe Božić on the occasion of the 2018 Croatian Book Month.

\subsection{Goal 11_Sustainable cities and communities: Make cities and human settlements inclusive, safe, resilient and sustainable}

European Union regulations, which Croatia has integrated into its legal system, prescribe the application of energy efficiency measures, environmental protection and the use of 
Zobundžija, V., Dolaček-Alduk, Z.

The role of higher education libraries in promoting sustainable development - an example of the practice of the library at the Faculty of Civil Engineering and Architecture Osijek

renewable energy sources. In the general consumption sector, buildings are large energy consumers, accounting for about $40 \%$ of total energy consumption in Europe and Croatia, with a constant growth trend. That is why a priority for energy and construction industries is the energy efficiency in building construction and the use of renewable energy sources, primarily for heating and cooling. The concept of sustainable construction requires an integrated approach to design, from concept to detail, where each structural element achieves the set energy efficiency specifications. In this way, the equipment and plant elements related to energy saving become equal to the basic components of building design: function, structure and form.

Such an approach to the design and construction of buildings has the effect that environmental issues are treated in science and higher education. The study programs of civil engineering at the undergraduate and graduate levels include topics in the field of energy efficiency in buildings construction, which are realized through the courses Building Physics, Energy Efficient Buildings and Integrated Design, while at the postgraduate level they are realized through the courses Building Management and Ecological Construction Technologies. The Library strives, as much as possible, to provide the prescribed compulsory literature in the number of copies of an individual title corresponding to $20 \%$ of students attending a particular course, and supplementary literature in the number of $10 \%$ of students.

In addition to printed materials, books and journals, students are offered links to e-books and journals in open access in the catalog and on the web page. The most common subject headings used in the catalog for literature search in the field of sustainability and environmental protection are: sustainable development, environment - pollution, renewable energy sources, energy efficiency, solar energy, energy - management, waste management, and environmental, nature and water protection. The latest standards in the fields covered by the curriculum are also followed and obtained, and they are available for work in the reading room.

\subsection{Goal 13_Climate protection: Take urgent action to combat climate change and its impacts}

In 2018, the Faculty of Civil Engineering and Architecture Osijek organized a number of professional lectures under the common title 24Hours for Sustainable Construction on the occasion of the international celebration of Earth Day on 22 April. Topics of the lectures, without exception aimed at educating and strengthening the approach to sustainable construction, application of environmental materials in construction and the use of modern technologies when conducting supervision and inspection of buildings, encouraged Faculty librarians to take a more active role in informing and promoting sustainable development in their community. The Library joined the program of the symposium with a presentation on green libraries and thus symbolically joined the Green Library project. The Library plans to implement environmental library programs and services, aimed at raising awareness and information about a sustainable society and environmental protection, through a wide range of activities: lectures, workshops, book presentations, thematic exhibitions and formation of thematic collections of library materials, but also by involvement in activities and projects of the local community.

In the past three years, the Green Library of the Faculty of Civil Engineering and Architecture prepared several thematic exhibitions of books from its holdings in the reading room on important environmental dates: World Environment Day on 5 June, International Biodiversity Day and Nature Protection Day in Croatia on 22 May, Earth Day on 22 April and World Water Day on 22 March. 
Zobundžija, V., Dolaček-Alduk, Z.

The role of higher education libraries in promoting sustainable development - an example of the practice of the library at the Faculty of Civil Engineering and Architecture Osijek

On 20 September 2018, the Croatian Green Building Council, in cooperation with the Faculty of Civil Engineering Osijek, organized the Green Talks program with the topic Energy renovation of buildings and nZEB (nearly Zero-Energy Buildings), which covered ZEB legislation and implementation on the market, as well as the topic of financing the energy renovation of buildings through EU funds, public-private building financing model EenU, completed and planned energy renovation projects, and opportunities for improvement and problems encountered in practice. The FCEAO Green Library also participated in the conference with two promotional exhibitions - books from the library holdings related to the topics discussed at the conference (green building, energy efficiency, smart homes, environmental protection) were exhibited, and a poster with basic information on the Green Library project was also posted.

At the $43^{\text {rd }}$ Assembly of the Croatian Library Association in Opatija from 10 to 13 October 2018, library activities for sustainable development were presented with a poster presentation Active role of the library of the Faculty of Civil Engineering Osijek in promoting sustainable development, prepared by Vesna Zobundžija, Library manager, and professors Zlata Dolaček-Alduk and Dina Stober, members of the FCEAO Library Board.

World Environment Day is celebrated on 5 June every year in more than 140 countries of the world. At the initiative of the United Nations, on this day world governments and organizations launch actions promoting the importance of environmental protection. On this occasion, the FCEAO Green Library organized the lecture Traditional House of Slavonia and Baranja in 2019. Sanja Lončar Vicković, Ph.D., and Dina Stober, Ph.D., gave an interesting and educational lecture, which was attended by students and professors of the Faculty of Civil Engineering in Subotica. Before the lecture, the Library manager presented the Green Library project and showed why the FCEAO Library is a green library (Figure 4). On the occasion of the World Green Building Week, an exhibition on sustainable construction Green Materials for a Sustainable Planet was set up in the Faculty hall from 21 to 25 September 2019, presenting in text and image selected examples of biophilic design, self-sustainable houses, structures made of recycled materials and green roofs in environmental architecture designs (Figure 5).

A screening of the feature-length documentary Infinite Happiness, about "the best residential building in the world", the famous 8 Tallet (Eight) located in the suburbs of Copenhagen, was organized as part of the 2020 Croatian Book Month for students of the university graduate study of Civil Engineering. It was designed by award-winning architect Bjarke Ingels and was inspired by the concept of permaculture.

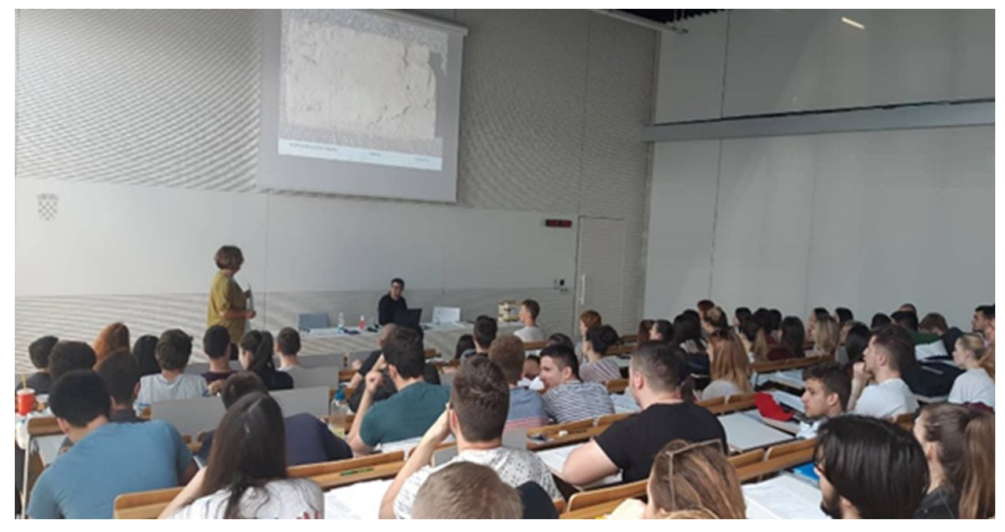

Figure 4. Lecture Traditional House of Slavonia and Baranja on the occasion of the 2019 World Environment Day 
Zobundžija, V., Dolaček-Alduk, Z.

The role of higher education libraries in promoting sustainable development - an example of the practice of the library at the Faculty of Civil Engineering and Architecture Osijek

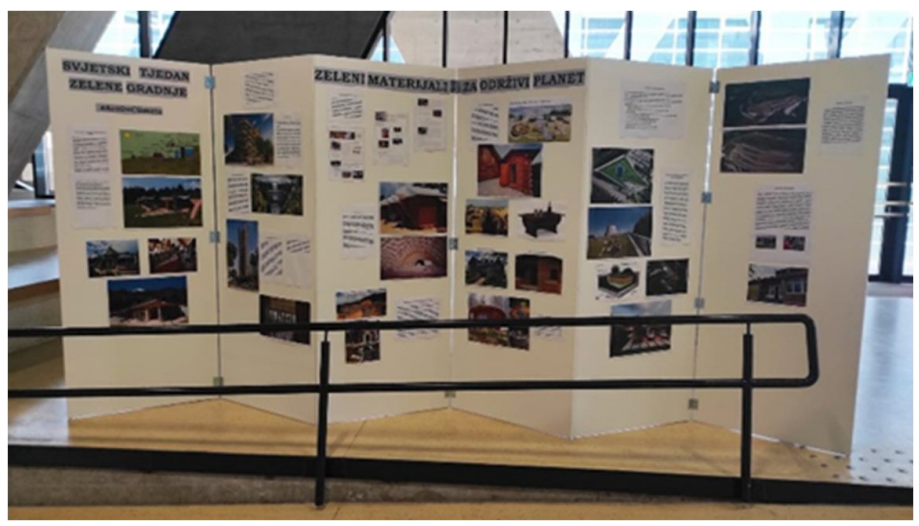

Figure 5. Exhibition Green Materials for a Sustainable Planet on the occasion of World Green Building Week from 21 to 25 September 2020.

In addition to these programs, the FCEAO Green Library strives to connect with the local community by participating in activities that educate its users, but also sensitize them to the problems of society and the environment in which they live. In early 2019, it joined the project Plastic Caps for Expensive Medicines, initiated by the Croatian Association of Leukemia and Lymphoma Patients (UOLL) in order to purchase expensive medicines for patients with severe malignant diseases by selling this valuable raw material. Three boxes for collection of caps were placed, appropriately marked, the drive was announced by posters, posts on the web and Facebook page, and through local media citizens were also invited to participate.

In November 2019, a civic initiative gathered around the Facebook group Dwarf Rhapsody organized planting of trees on the university campus in cooperation with the Josip Juraj Strossmayer University of Osijek. The FCEAO Library also joined the drive, and the employees and the Student Union of the Faculty responded. As part of the celebration of the 2020 Croatian Book Month, a "Keep the Tree" challenge was organized, inviting second-year students of the university undergraduate study of Civil Engineering to take over and care for a young linden tree and keep it for the next generation to take charge until the small tree is strengthened for planting.

As part of the green activities, the Library organized for students and employees of the Faculty a visit to the family farm Čudesna šuma (Miraculous Forest) in Bilje, an eco-farm where fruits and vegetables are produced according to the principles of biodynamic cultivation and where they could hear a lot of useful information about ecological food growing, soil revitalization, permaculture and biodiversity.

Library employees strive to create an environmentally friendly work environment and by their behavior and actions to be an example and develop awareness of the necessity to change bad habits: in order to reduce unnecessary paper consumption, printed correspondence is replaced by e-mail communication, document printing and copying are optimized, waste is separated, and part also recycled, disposable plastic cups are replaced with glass ones, and plastic bags with paper ones. The space of the reading room and the Legere Club is enriched with greenery and flowers. 
Zobundžija, V., Dolaček-Alduk, Z.

The role of higher education libraries in promoting sustainable development - an example of the practice of the library at the Faculty of Civil Engineering and Architecture Osijek

\subsection{Goal 16.10_Ensure public access to information and protect fundamental freedoms in accordance with national legislation and international agreements}

The Library of the Faculty of Civil Engineering and Architecture Osijek provides users with access to information in multiple ways. The entire library holdings can be browsed in the online catalog that covers books, journals, master's and doctoral theses of our professors, but also relevant professional and scientific papers, standards and electronic materials. The catalog is available through a link on the library's web page, and it also contains a bulletin of newly acquired books, which is published semi-annually.

The digital institutional repository Dabar, which enables storage, description, long-term keeping, search and distribution of the institution's digital content, was established in late 2015, first at the national and then at the university level. The Library became part of the repository at the very beginning, and to date, about 1500 student evaluation papers (final, graduation papers and dissertations) and scientific and professional papers of our employees have been entered. All doctoral, professional and scientific papers are in open access, with which we strongly support the Croatian Open Access Declaration. Thanks to this, the FCEAO Repository was among the first higher education repositories to be included in the OpenDOAR and OpenAIRE repositories.

Access to online information, but also transparency of the library's operations, is ensured through a page on the Faculty's website. The page is regularly updated with current information and news about purchased books, journals, educational content for students and teachers, presentations and links to online books, journals, databases, manuals, guides and dictionaries. The page also offers the Ask the Librarian service and an online literature search form for seminar, final or graduation papers.

The Library's Facebook page was activated in early 2016, and the Instagram profile in 2020. The purpose of these pages is to make the library more visible and accessible to users and to inform them in time about new books, services, activities and events that are being organized. By continuous, active and up-to-date monitoring of all relevant information sources, information can be transferred regularly and in real time, additionally accompanied by a photo, video or link. In addition, the possibility is opened for two-way communication, for asking questions and for comments on posts. Students received the library on Facebook very well, thus confirming that social networks are a useful and desirable marketing tool for promoting library activities and that they can greatly contribute to their recognizability and improvement of customer relationships [12].

\section{CONCLUSION}

The first condition for achieving any of the proclaimed goals of the UN 2030 Agenda for Sustainable Development is a change in the ingrained habits of people, and this is possible through education, among other things. Libraries have a traditional role and mission of storing and keeping, but also providing access to knowledge and information. Higher education libraries have an important place in education and information. They are an integral part of the scientific and educational activities of faculties, they are their intellectual center, center of information and knowledge, a meeting and learning place. They are undoubtedly among the most important resources in the quality system and an indispensable part of the institution's self-evaluation during the re-accreditation of the faculty. In order to present both themselves and their institution in the best possible way, their services are expanded and changed with the help of information and communication technology, which 
Zobundžija, V., Dolaček-Alduk, Z.

The role of higher education libraries in promoting sustainable development - an example of the practice of the library at the Faculty of Civil Engineering and Architecture Osijek

has a positive effect on the quality of service, but also shows responsibility towards the society and natural resources.

The Library of the Faculty of Civil Engineering and Architecture Osijek has accepted its expanded role in promoting the values of socially responsible operation and the demands of an environmentally aware society, striving to help achieve the planned outcomes of sustainable development goals related to education and access to information, environmental protection and sustainable construction.

Efforts are made to ensure high-quality education by equipping a comfortable and functional space for learning and work, as well as space for rest and leisure of students, then by taking care to provide the prescribed compulsory and supplementary literature in a sufficient number of copies, by the offered information and educational materials on the Library web page and by organizing lectures and workshops for students and teaching staff. Following the global trends in adapting curricula to the creative economy, the Library has become a cultural center of the Faculty and the initiator of creative activities, related primarily to celebrations of international and national events, that promote the importance of books and libraries, encourage a culture of reading and writing, develop respect and care for one's own language and cultural heritage, as well as for understanding and awareness-raising of climate change issues and pollution and environmental threats.

In the last 20 years, there have been numerous initiatives for open access to information, or for "unrestricted, free, and undisturbed online access to digital scientific information that allows scientific information to be read, stored, distributed, searched, reached, indexed and/or used in any other legal way" [13]. It is at the time of the COVID-19 pandemic that digital, media and information literacy, which opens up the possibility of participating in digital platforms, proved to be more important than ever. On its web page, the FCEAO Library offers links to its online catalog, bulletins of new acquisitions, lists of subscribed journals in printed form and links to online accessible journals, e-books and databases. Relevant online dictionaries, manuals, encyclopedias, language advisors, as well as links to available presentations and webinars are identified and recommended. The Library also manages and edits the digital repository of the Faculty of Civil Engineering and Architecture, regularly entering all student evaluation papers and professional and scientific papers of the Faculty employees, which are in open access. Social networks, especially Facebook, which students like to use as a platform for communication with librarians, also play an important role in presentation and visibility of library services and activities.

The Green Library activities are intended to promote green literacy, i.e. to raise awareness and sensitivity to environmental challenges, to motivate users to improve the quality of the environment and to help and participate in activities that can help solve environmental challenges. In addition to educational activities such as thematic book exhibitions, lectures and screenings of documentaries, the Library motivated its users to participate in planting trees in the vicinity of the Faculty and visit the ecological farm, thus connecting with the local community. Each country's energy sector affects its economic activity and economic growth and has an important impact on the environment. The biggest problems facing the world in terms of sustainable development are related to increased energy consumption, insecurity in energy supply, the constant rise in prices of energy and energy sources, environmental pollution and climate change caused by irrational consumption. Considering the seriousness of the problem, the awareness of the need to manage energy development, reduce import dependence and use energy rationally has grown in all countries of the European Union, and thus in our country too. Sustainable development has become a major goal of all strategies at the global and national levels, as well as of the legislative framework that results from their adoption. In addition to teaching contents in the field of sustainable construction, activities of the FCEAO Library are aimed at strengthening the teaching process by taking on the role of information center, by activities popularizing science and promoting sustainable construction programs. 
Zobundžija, V., Dolaček-Alduk, Z.

The role of higher education libraries in promoting sustainable development - an example of the practice of the library at the Faculty of Civil Engineering and Architecture Osijek

\section{REFERENCES}

1. Pojmovnik: Kako povećati uključenost lokalne samouprave u promicanje procesa lokalnog održivog razvoja kroz decentralizirane javne politike i provedbu aktivnosti DEAR-a, available

on: http://www.hils.hr/download/dearstudent/Glossary\%20of\%20terms.pdf) (cited: 2021-0105)

2. Our Common Future, Chapter 2: Towards Sustainable Development. // Our Common Future: report of the World Commission on Environment and Development. UN Documents, A/42/427, cited according to Dragaš, B.: Zelene knjižnice za zelenu pismenost: hrvatsko iskustvo, Vjesnik bibliotekara Hrvatske 60, 4 (2017), 221-241 (cited: 2021-01-06)

3. The Talloires Declaration: 10 Point Action Plan, available on: http://ulsf.org/wpcontent/uploads/2015/06/TD.pdf

4. Čadovska, I.; Tkalčić, A-M.: Zelena pismenost kao dio strategije razvoja informacijske službe, Vjesnik bibliotekara Hrvatske 60, 1 (2017), 65-77

5. Dragaš, B.: Zelene knjižnice za zelenu pismenost: hrvatsko iskustvo, Vjesnik bibliotekara Hrvatske. 60, 4 (2017), 221-241

6. International Federation of Library Associations and Institutions: Pristup i mogućnost svima: kako knjižnice doprinose ostvarivanju Agende Ujedinjenih naroda za održiv razvoj 2030, Electronic publications of the Croatian Library Association, Vol. 7. Croatian Library Association, 2018, available on: http://www.hkdrustvo.hr/hr/izdanja/kategorija/elektronicka (cited: 2021-01-06)

7. Leko Šimić, M.; Mihaljević, J.; Tolušić, M.: Academic libraries and the social responsibility challenge, $7^{\text {th }}$ International Scientific Symposium Economy of Eastern Croatia - Vision and Development, Proceedings, Josip Juraj Strossmayer University of Osijek, Faculty of Economics in Osijek, 2018, 650-659

8. Kraljević, I.: Djelovanje Radne grupe za zelene knjižnice 2014.-2018., Vjesnik bibliotekara Hrvatske, 62, 1 (2019), 327-340

9. Brbora, S.: Novosti obojene zeleno, HKD Novosti, 82 (2020) (cited: 2021-01-10)

10. Čunović, K.: Razvoj Gradske knjižnice „Ivan Goran Kovačić“ na načelima ekološke održivosti (Development of the Public Library „Ivan Goran Kovačić" on the Principles of Ecological Sustainability), Knjižničarstvo 24, 1-2 (2020), 65-80

11. Vuksanović, D.: Prilog kritici koncepta Kreativnog univerziteta (Contribution to the Critique of the Concept of "Creative University"), Metodički ogledi 20 (2013) 1, 45-60

12. Zobundžija, V.; Dragun, E.: Knjižnice Osječkog sveučilišta na Facebooku: zašto nam je lajkanje važno?, Vjesnik bibliotekara Hrvatske 63, 1-2 (2020), 227-252

13. Croatian Open Access Declaration, 2012., available on https://www.fer.unizg.hr/oa2012/deklaracija (cited: 2021-02-04) 